\title{
Tumor Markers in Breast Cancer - European Group on Tumor Markers Recommendations
}

\author{
Rafael Molina ${ }^{a}$ Vivian Barak $^{b}$ Arie van Dalen ${ }^{c}$ Michael J. Duffy ${ }^{e}$ \\ Roland Einarsson ${ }^{f}$ Massimo Gion $^{\text {h }}$ Helena Goike ${ }^{g}$ Rolf Lamerz ${ }^{i}$ \\ Marius Nap ${ }^{d}$ György Sölétormos ${ }^{k}$ Petra Stieber ${ }^{j}$ \\ ${ }^{a}$ Laboratory of Biochemistry, Hospital Clinic, Medical School, Barcelona, Spain; ${ }^{\mathrm{b}}$ Immunology and \\ Tumordiagnostics Laboratory, Hadassah University Jerusalem, Jerusalem, Israel; ' Institute of Tumor Marker \\ Oncology, Gouda, ${ }^{d}$ Pathology Department, Atrium Medical Center Heerlen, Herleen, The Netherlands; \\ ${ }^{e}$ Department of Nuclear Medicine, St Vincent's University Hospital, Dublin, Ireland; ${ }^{f}$ CanAg Diagnostics AB,

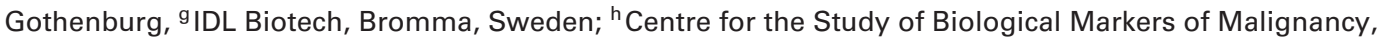 \\ General Regional Hospital Azienda ULSS 12, Venice, Italy; 'Medizinische Klinik II and \\ ${ }^{\mathrm{j} I n s t i t u t ~ f u ̈ r ~ K l i n i s c h e ~ C h e m i e, ~ K l i n i k u m ~ G r o s s h a d e r n, ~ M u ̈ n c h e n, ~ G e r m a n y ; ~}{ }^{\mathrm{k}}$ Department of Clinical Biochemistry, \\ Hillerød Hospital, Hillerød, Denmark
}

\section{Key Words}

Breast cancer - Tumor markers · European Group on

Tumor Markers

\begin{abstract}
Recommendations are presented for the routine clinical use of serum and tissue-based markers in the diagnosis and management of patients with breast cancer. Their low sensitivity and specificity preclude the use of serum markers such as the MUC-1 mucin glycoproteins (CA 15.3, BR 27.29) and carcinoembryonic antigen in the diagnosis of early breast cancer. However, serial measurement of these markers can result in the early detection of recurrent disease as well as indicate the efficacy of therapy. Of the tissue-based markers, measurement of estrogen and progesterone receptors is mandatory in the selection of patients for treatment with hormone therapy, while HER-2 is essential in selecting patients with advanced breast cancer for treatment with Herceptin (trastuzumab). Urokinase plasminogen activator
\end{abstract}

and plasminogen activator inhibitor 1 are recently validated prognostic markers for lymph node-negative breast cancer patients and thus may be of value in selecting node-negative patients that do not require adjuvant chemotherapy.

Copyright (C) 2005 S. Karger AG, Basel

\section{Introduction}

Breast cancer accounts for approximately $35 \%$ of all cancers in Western females, with half the cases occurring in women less than 55 years old [1]. Multiple factors are associated with increased breast cancer risk [2-8]. While breast cancer incidence has increased over the last 30-40 years, mortality has remained stable, probably reflecting earlier diagnosis as well as improved treatment options $[9,10]$. The latter include surgery, radiotherapy, chemotherapy, hormonal therapy and immunotherapy. The initial treatment of localized primary breast cancer is given with curative intent and usually includes surgery and/or

\section{KARGER}

Fax +4161306 1234 E-Mail karger@karger.ch www.karger.com (c) 2005 S. Karger AG, Basel 1010-4283/05/0266-0281\$22.00/0

Accessible online at: www.karger.com/tbi
Dr. Rafael Molina

Laboratory of Biochemistry

Hospital Clinic, Medical Schoo

ES-08036 Barcelona (Spain)

Tel./Fax +349345122 03, E-Mail rmolina@clinic.ub.es 
radiotherapy. In recent years, the prognosis for patients with breast cancer has improved due to the administration of adjuvant hormonal therapy and adjuvant chemotherapy $[11,12]$. Currently, in the developed world, over $70 \%$ of patients with a diagnosis of breast cancer survive 5 years or more [13, 14].

Rational administration of these expensive and frequently unpleasant treatments requires identification both of those patients with localized disease at most risk of recurrence and those who have distant metastases or micrometastases which are unlikely to respond to local therapies $[15,16]$. Therefore, objective methods for assessing response to treatment in patients receiving such therapies are highly desirable. In this article, we consider how the measurement of tumor markers in serum and tissue can best contribute to this assessment, presenting the recommendations of the European Group on Tumor Markers (EGTM) (table 1), and where appropriate comparing these markers with those of other expert panels $[17,18]$.

\section{Serum Tumor Markers}

Numerous serum tumor markers have been described for breast cancer, including members of the MUC-1 family of mucin glycoproteins (e.g., CA 15.3, BR 27.29, MCA, CA 549), carcinoembryonic antigen (CEA), oncoproteins (e.g., HER-2/c-erbB-2) and cytokeratins (e.g., tissue polypeptide antigen and tissue polypeptide-specific antigen) [19-24]. Members of the MUC-1 family are the most widely used serum tumor markers in breast cancer, but as they have similar diagnostic sensitivities and specificities, the use of more than one MUC-1 antigen is unlikely to confer any advantage [19, 20, 25]. However, CEA measurement can provide additional complementary information. For this reason, the combination of one MUC-1 marker and CEA is the recommended serum marker panel in patients with breast cancer.

\section{Screening and Diagnosis}

Their lack of organ and tumor specificity and low sensitivity, particularly in early-stage disease, generally invalidate the use of tumor markers for either screening or early diagnosis $[17,22]$. Low levels of tumor markers in patients with suspected breast cancer never exclude the presence of malignancy. Nevertheless, tumor marker determination may complement patient staging: high levels of CA 15.3 (e.g. $>50 \mathrm{U} / \mathrm{ml}$ ) and/or CEA (e.g. $>20 \mathrm{ng} / \mathrm{ml}$ )
Table 1. Serum markers in breast cancer: EGTM recommendations

\section{Serum markers}

The most useful serum markers for breast cancer are CA 15.3 (or BR 27.29) and CEA, but due to their low sensitivity, they cannot be recommended for screening or early diagnosis, but serial levels may be useful in the early diagnosis of distant metastases.

Prognosis: Preoperatively elevated levels of either CA 15.3 or CEA are associated with adverse outcome in patients with breast cancer; their use in combination with established prognostic factors is recommended.

Early diagnosis of recurrence: Serial CA 15.3 and CEA serum determinations are recommended for the early detection of recurrence in patients with breast cancer and no evidence of disease, if the detection of recurrent or metastatic disease would alter clinical management. The impact of this lead time information on patient outcome is not clear.

Therapy monitoring: Markers should be measured prior to every chemotherapy course and at least every 3 months for patients receiving hormone therapy.

The EGTM regards an increase in tumor marker concentration of at least $25 \%$ of the previous value - with the second value above the reference interval - to be significant. It is recommended that such an increase be confirmed with a second specimen obtained within a month. If the continued increase is confirmed, this provides evidence of progressive disease. Similarly, confirmed decreases in serum levels of more than 50\% are consistent with tumor response.

Technical aspects: Well-documented and relevant IQC and EQA procedures must be in place and should be followed whenever tumor markers are measured. If it is necessary to change method during serial monitoring, this must be undertaken with considerable care.

\section{Tissue markers}

ER and PR should be assayed on all newly diagnosed breast cancer patients. The primary use of steroid receptors is for selecting patients for treatment with hormone therapy.

HER-2 should be used for selecting patients with advanced breast cancer for treatment with Herceptin and for identifying patients with early breast cancer for participation in clinical trials involving adjuvant Herceptin. HER-2 may also be of use for identifying patients who are particularly likely to benefit from adjuvant anthracycline-based chemotherapy.

HER-2 should not be used to predict response to either hormone, CMF or taxane therapy.

For determining HER-2 status, immunohistochemistry (calibrated against FISH) should be employed. For samples with an immunohistochemistry score of $2+$, confirmation by FISH should be carried out.

UPA and PAI-1, determined by a validated ELISA, may be used for determining prognosis, especially in patients with lymph node-negative disease. 
in patients thought to have localized disease suggest the presence of unsuspected metastatic disease.

The sensitivity of tumor markers is significantly higher in patients with advanced disease $[21,26-38]$ and is related to the site of recurrence $[18,30,39]$. CA 15.3 and CEA are not useful in the early diagnosis of locoregional recurrence, for which clinical examination is superior. However, abnormal CEA and CA 15.3 levels are found in $40-50$ and $50-70 \%$ of patients with distant metastases [40-43]. Simultaneous use of both markers allows early diagnosis of metastases (mainly in bone and liver) in up to $60-80 \%$ of patients with breast cancer. By using combinations of several markers (e.g., CA 15.3, CEA and cytokeratins), it is possible to increase the sensitivity to at least $90 \%$ in patients with distant metastases $[24,33,34$, 44-46].

\section{EGTM Recommendation}

The most useful serum markers for breast cancer are CA 15.3 (or BR 27.29) and CEA, but due to their low sensitivity, they cannot be recommended for screening or early diagnosis.

\section{Prognosis}

Serum levels of CA 15.3 (and other MUC-1 glycoproteins) and CEA are related to tumor burden, with significantly higher values in patients with nodal involvement or large tumors [18, 26-28, 47]. Several studies have demonstrated shorter disease-free survival and overall survival in patients with high preoperative levels of these markers, while others reported conflicting data [18-20, 27-29, 48-52]. Most studies with large patient groups and long follow-up times conclude that preoperative serum CA 15.3 and CEA concentrations are independent prognostic factors $[28,29,50-55]$. However, it has not yet been demonstrated if the use of tumor markers as indicators of recurrence can lead to improvement in either patient disease-free survival or overall survival.

\section{EGTM Recommendation}

Preoperatively elevated levels of either CA 15.3 or CEA are associated with adverse outcome in patients with breast cancer, and the EGTM recommends their measurement in combination with established prognostic factors.

\section{Early Detection of Recurrence}

The main reasons for monitoring patients following treatment for primary breast cancer are to enable the early detection of new primary or locally recurrent cancers that may be cured by early intervention, as well as the early detection of metastatic disease. The sensitivity of tumor markers for detecting recurrent disease is clearly related to the site of recurrence [40-43]. As previously described, low sensitivity precludes the use of tumor markers in the early diagnosis of locoregional recurrence, but serial tumor marker measurements can contribute usefully to early diagnosis of distant metastatic disease, especially in liver and bone. Increases in MUC-1 serum markers reportedly provide the first indication of recurrence, prior to clinical or radiological indication (e.g., by chest X-ray, liver ultrasonography, bone scans), in $40-55 \%$ of treated patients $[40-42,56]$. Additional CEA measurement can increase the sensitivity in the early detection of recurrence obtained with CA 15.3 by up to $5-25 \%$ of the patients [40]. Reported lead times vary from 2 to 18 months (mean 5.2) [30-32, 40$43,55-62]$.

The specificity of markers for the detection of recurrence in the follow-up of patients with no clinical evidence of disease is related to the marker cut-off points used [30-32, 40-43, 56-58, 60-64]. In one study, the proportion of false-positive results (abnormal values without recurrence) was 5\% for CEA and $6.5 \%$ for CA 15.3 using cut-off values of $5 \mu \mathrm{g} / \mathrm{l}$ and $35 \mathrm{U} / \mathrm{ml}$, respectively [40]. Using higher cut-off values (CEA $10 \mu \mathrm{g} / 1$, CA $15.360 \mathrm{U} / \mathrm{ml})$ and at least two serial increases $(>15 \%)$, specificity increased to almost $100 \%[41,58]$. Using the latter criteria, sensitivities of 45 and 30\% have been reported for CA 15.3 and CEA, respectively, with an increase in either tumor marker providing the first sign of recurrence in $60-70 \%$ of patients [41, 42].

Early detection of metastasis has two different aims: one is the diagnosis, and the second, the possibility to earlier initiate systemic treatment. There is a controversy as to whether intensive screening incurs extra expenses and whether it unnecessarily increases anxiety; additionally, its value is uncertain regarding ultimate outcome $[64,65]$. Other diagnostic tools such as chest radiography, bone scans and liver ultrasonograms are useful in the diagnosis of recurrent or metastatic disease but do not seem to increase survival [66-68]. In spite of the previously reported studies, the basic hypothesis that early diagnosis of recurrences may prolong survival is supported by the observation that smaller breast tumors generally are more likely to respond to therapy than larger tumors. The inverse relationship between tumor mass and chemotherapy response means that in more advanced metastatic disease, response to treatment is generally shorter and less likely [69]. 


\section{EGTM Recommendation}

The EGTM recommends serial CA 15.3 and CEA serum determinations for the early detection of recurrence in patients with breast cancer and no evidence of disease, if the detection of recurrent or metastatic disease would alter clinical management, although the impact of this lead time information on patient outcome is not clear. Currently, there are no data available regarding the optimum frequency for the measurement of serum tumor markers in the early diagnosis of recurrent disease. However, the EGTM panel suggests the following approach during the follow-up of asymptomatic women: tumor markers should be determined every $2-4$ months (according to the risk of recurrence) during the initial 5 years after diagnosis, then every 6 months during the next 3 years and at yearly intervals thereafter.

\section{Therapy Monitoring}

The most important clinical application of tumor markers in metastatic breast cancer lies in monitoring response to therapy. Patients in remission usually have decreasing marker levels, while those with progressive disease generally have increasing levels $[33,35,37,38$, $44,45,70-72]$. Studies comparing tumor marker monitoring with conventional International Unit against Cancer criteria vary considerably - both in terms of the disease status of included patients and the criteria for marker assessment - but most authors conclude that the measurement of tumor markers provides an objective means of guiding therapy [33-36, 57-63, 70-76].

\section{Frequency of Measurement}

It depends on the treatment how frequently markers should be measured. The EGTM recommends that tumor markers in patients treated with chemotherapy should be determined before every chemotherapy course. In patients treated with hormone therapy, they should be measured at least every 3 months.

\section{Defining Significant Changes}

There is little agreement in the literature about what constitutes a clinically significant change in marker level. The EGTM regards an increase in tumor marker concentration of at least $25 \%$ of the previous value - with the second value above the reference interval - to be significant, recommending that such an increase be confirmed in a second specimen obtained within a month. If the continued increase is confirmed, this provides evidence of progressive disease. Similarly, confirmed decreases in serum levels of more than $50 \%$ are consistent with tumor response, to avoid the intraindiviual as well as the interassay variability [33-35, 46, 77-79]. Certain treatments may cause transient increases in serum marker levels, so that increases observed shortly after treatment must always be confirmed.

Advantages of Tumor Marker Monitoring

Monitoring with tumor markers has been shown to be superior to monitoring by conventional International Unit against Cancer criteria in a number of studies [33$35,46,77-83]$. Biochemical changes often precede clinical or radiological signs of response or progression, potentially enabling earlier treatment decisions regarding continuation of effective therapy, discontinuation of ineffective therapy, change of therapy or more effective palliation. It has been suggested that biochemical assessment may result in cost savings of at least $50 \%$ when compared with assessment by clinical or radiological criteria, which often require expensive imaging techniques such as computer tomography scans [82]. However, whether this monitoring leads to enhanced survival or better quality of life remains to be determined [83, 84].

\section{EGTM Recommendation}

Markers should be measured prior to every chemotherapy course and at least every 3 months for patients receiving hormone therapy. Objective criteria for assessing changes in markers should be in place and increases or decreases confirmed appropriately.

\section{Measurement of Serum Markers}

Analytical requirements for tumor markers are similar to those for most other clinical analytes: the correct and appropriate specimen should be analyzed by a method which meets defined quality requirements for both internal quality control (IQC) and external quality assessment (EQA) [85].

Tumor marker assays from different manufacturers can give significantly different results for the same serum [86-88]. The method used should therefore be stated on the laboratory report. When it is necessary to change the method used to monitor a patient during follow-up, this should be undertaken with considerable care, e.g., by assaying a specimen using both methods for a period of time, so as to minimize the risk of misinterpretation of trends in marker levels. 


\section{EGTM Recommendation}

Well-documented and relevant IQC and EQA procedures must be in place and should be followed whenever tumor markers are measured. If it is necessary to change the method during serial monitoring, this must be undertaken with considerable care.

\section{Tissue Markers}

While serum markers in breast cancer are mostly used for monitoring patients with diagnosed disease, tissuebased markers are primarily measured in order to determine prognosis and predict response to therapy. Clinically, the most useful tissue-based markers in breast cancer are estrogen receptor (ER), progesterone receptor (PR) and HER-2 (also known as c-erbB-2 or neu). Although not yet in widespread clinical use, urokinase plasminogen activator ( $\mathrm{UPA}$ ) and plasminogen activator inhibitor 1 (PAI-1) are potential markers for determining prognosis in lymph node-negative breast cancer patients.

\section{$E R$ and $P R$}

ER and PR are transcriptional factors which mediate the actions of estrogens and progesterone, respectively $[89,90]$. Both receptors are now known to exist in two different forms. For ER, these forms are known as ER-alpha and ER-beta [91], and for PR, the two forms are known as PRA and PRB [92]. To date, for ER, a clinical role has only been established for the alpha form. Existing assays for PR do not discriminate between the two forms.

The main clinical application of ER (i.e. ER-alpha) and PR in breast cancer is selecting patients likely to respond to hormone therapy. In both early and advanced disease, hormone receptor-positive patients have a significantly greater probability of responding to hormone therapy than patients lacking receptors [93-95]. Therefore, the EGTM panel recommends that ER (i.e. ER-alpha) and PR assays be performed on all patients with newly diagnosed breast cancer. Similar recommendations have been previously made by the EGTM [26, 96], as well as by other expert panels such as the American Society of Clinical Oncology (ASCO) [17, 97], the National Academy of Clinical Biochemistry [96], the European Society of Medical Oncology [98], the European Society of Mastology [99] and a National Institute of Health developmental panel [100]. At this stage, the assay of ERbeta cannot be recommended for predicting response to endocrine therapy.

Tumor Markers in Breast Cancer
While the primary purpose for performing hormone receptor assays lies in selecting a likely response to endocrine therapy, information on receptor status or concentration may also be of prognostic value. Generally, for the first 4-5 years after diagnosis, ER-positive patients have a better outcome than ER-negative patients [101, 102]. However, after this period, the favorable prognostic impact of ER is lost. A further limitation of ER as a prognostic factor is that it is of little value in lymph nodenegative patients [101, 102]. Although less work has been carried out on the prognostic impact of PR, patients with tumors expressing PR also tend to have a better prognosis than those lacking this receptor $[95,103]$.

\section{Measurement of $E R$ and $P R$}

Three well-established assays exist for measuring hormone receptors, namely ligand binding, ELISA and immunohistochemistry. It is important to state that all the early studies showing a clinical utility for hormone receptors were performed with ligand-binding assays. However, more recently, immunohistochemistry has largely replaced the older biochemical assays for determining receptor levels. Immunohistochemistry is simpler to perform than either ligand-binding assays or ELISA and has the distinct advantage of being the only assay that can be used for small tumors. Furthermore, at least for ER, immunohistochemistry assays have been shown to perform as well as the ligand-binding assays for predicting response to hormone therapy [104-110]. Therefore, for the present, the EGTM recommends that immunohistochemistry should be used to determine hormone receptors in breast cancers.

For immunohistochemistry, some of the most widely validated antibodies include 6F11 MAb or antibody ID5 for ER [104, 105, 111, 112] and antibodies PR88 KD68 MAb or MAb 1294 for PR [105, 111-113]. Scoring of immunohistochemical stain may be based on either percentage of cells stained or a combination of percentage of cells stained plus intensity of stain $[111,112]$. The hormone receptor report should indicate this semi-quantitative score, rather than merely stating a negative or positive finding $[111,112]$.

A new approach, using a combination of DNA flow cytometry and immunophenotyping on single cell suspensions from formalin-fixed paraffin-embedded tissue, has the advantage of both objective quantitation and application to small amounts of tissue. Furthermore, the quality of the DNA histograms serves as an internal control for the preservation of receptor proteins. Although this is a novel method for the quantitative determination 
of markers in tissue and has been subjected to several studies $[114,115]$, it has not yet found wide acceptance, since a possible improved correlation with clinical outcome has not yet been documented.

\section{EGTM Recommendations}

An assay of hormone receptors (i.e. ER and PR) is mandatory in the selection of patients with both early and advanced breast cancer for treatment with hormone therapy. Patients with hormone receptor-positive tumors should be treated with some form of endocrine therapy, while receptor-negative patients should receive an alternate form of therapy.

Immunohistochemistry with validated antibodies should be used to determine hormone receptors in breast cancer.

Since both ER and PR are relatively weak prognostic factors in breast cancer, these factors should not be used alone for differentiating between patients with indolent and aggressive breast cancers. However, hormone receptors may be combined with established prognostic factors in determining outcome.

\section{$H E R-2$}

HER-2, which is also known as c-erbB-2 or neu, encodes a transmembrane protein belonging to the epidermal growth factor receptor family [for a review, see ref. 116]. The HER-2 gene is either amplified or overexpressed in $15-30 \%$ of invasive breast cancers. Amplification of the HER-2 gene means that instead of having only 2 copies of the gene per cell, there may be 50-100 gene copies per cell. The number of HER-2 proteins per cell can then increase from 20,000-50,000 to as high as 2 million [117].

HER-2 has a number of potential uses in breast cancer, including determining prognosis, predicting relative resistance to both hormone therapy and adjuvant cyclophosphamide, methotrexate, 5-fluorouracil (CMF) therapy, selecting for enhanced response to adjuvant anthracycline-based therapy and identifying patients for treatment with Herceptin (trastuzumab). The role of HER-2 in these specific areas is now briefly discussed.

\section{Predicting Response to Herceptin}

Currently, the primary and only mandatory reason for determining HER-2 levels in breast cancer lies in selecting patients with advanced breast cancer for treatment with Herceptin (trastuzumab). Herceptin is a humanized $\mathrm{MAb}$ that binds with high affinity to the extracellular domain of HER-2, thereby blocking its role in signal transduction [118]. Herceptin, alone or in combination with chemotherapy, is now widely used for the treatment of HER-2-positive patients with advanced breast cancer. Furthermore, Herceptin is currently being evaluated in clinical trials for the adjuvant treatment of HER-2-positive breast cancer [119].

Based on cell culture and animal model experiments $[117,118]$, it is generally believed and highly likely that overexpression of HER-2 is necessary for Herceptin to induce tumor regression. Consequently, at this stage, Herceptin should only be administered to breast cancer patients showing either gene amplification or overexpression of HER-2. In agreement with the ASCO expert panel [97], the EGTM panel recommends an assay of HER-2 for selecting patients with advanced breast cancer for treatment with Herceptin.

Predicting Resistance to Endocrine Therapy

Most but not all published reports conclude that overexpression of HER-2 is associated with relative resistance to hormone therapy in patients with breast cancer [for reviews, see ref. 120,121]. Most of these studies have methodological limitations including a retrospective assay of HER-2, the use of different HER-2 assays and inclusion of relatively small numbers of patients. Furthermore, different forms of hormone therapy were used and different subgroups of patients were studied in the different trials. Based on present information, the EGTM panel is unable to recommend an assay of HER-2 for selecting endocrine resistance in patients with breast cancer. The ASCO [97] and National Institute of Health panel [100] have made similar recommendations.

\section{Predicting Response to Chemotherapy}

Similar to the situation with hormone therapy, controversy also exists on the relationship between HER-2 and response to adjuvant CMF. Although most studies conclude that patients with HER-2-positive tumors derive less benefit from adjuvant CMF than patients with HER2-negative cancers, there are again conflicting reports [for reviews, see ref. 120,121]. In general, studies on the relationship between HER-2 and response to CMF suffer from the same limitations as discussed above for endocrine therapy. Based on current findings, the EGTM panel, in agreement with the ASCO panel [97], is unable to recommended assay of HER-2 for predicting response to adjuvant CMF.

Although overexpression of HER-2 may be associated with relative resistance to adjuvant $\mathrm{CMF}$, a number of retrospective studies suggest that increased levels of this oncoprotein predicts an enhanced response from anthra- 
cycline-based adjuvant therapy [for reviews, see ref. 120, 121]. Indeed, the ASCO panel stated 'that high levels of HER-2 may identify patients who particularly benefit from anthracycline-based adjuvant therapy but that levels of HER-2 should not be used to exclude patients from anthracycline treatment' [97]. The EGTM panel supports this statement.

Compared with the response to CMF or anthracyclinebased therapy, relatively few studies have investigated the interaction between HER-2 and the benefit of taxanes. While some reports concluded that patients with HER-2-positive tumors exhibited higher response rates to taxanes in advanced breast cancer than those with HER-2-negative cancers [122], others were unable to confirm these findings $[123,124]$. In a recent retrospective study, Konecny et al. [125] reported that patients with HER-2-positive tumors had a greater objective response than patients with HER-2-negative tumors to treatment with epirubicin/paclitaxel when used as first-line chemotherapy for metastatic breast cancer. However, HER-2 was not associated with response to epirubicin/cyclophosphamide. Despite these promising findings, HER-2 cannot, at present, be recommended in selecting for response or resistance to taxanes [97].

\section{Determining Prognosis}

Most published reports on axillary node-positive breast cancer patients conclude that either HER-2 gene amplification or overexpression correlates with an adverse outcome in patients with breast cancer [for a review, see ref. 126]. However, the prognostic impact of HER-2 in node-negative breast cancer patients is less clear [126]. It is important to point out that most of the studies relating HER-2 to patient outcome were retrospective in design, contained relatively low numbers of patients and used a variety of HER-2 assays. Furthermore, in many of the studies, patients received different types of adjuvant therapy, making it difficult to differentiate a prognostic from a predictive impact. Based on the available information, the EGTM panel recommends that HER-2 should not be used alone for determining outcome in patients with breast cancer. However, as HER-2 is being measured on an increasing number of patients with breast cancer, information on HER-2 status may be combined with standard prognostic factors for determining outcome in patients with breast cancer.

Measurement of HER-2

Although multiple methods have been used to measure HER-2 gene amplification/protein overexpression in breast tumors, the two most widely employed methods are immunohistochemistry and fluorescent in situ hybridization (FISH). The advantages of immunohistochemistry include its wide availability, simplicity and relatively low costs. Its disadvantages include subjectivity in evaluating the staining score, possible loss of HER-2 protein as a result of tissue storage and fixation and variable results depending on both the antibody and staining procedure used.

In contrast to immunohistochemistry, FISH can theoretically provide a more objective scoring system. It also has the advantage of a built-in internal control consisting of two HER-2 gene copies in the non-malignant cells within the specimen. The disadvantages of FISH include its high costs, the requirement for a fluorescent microscope and the inability to preserve the slide for storage and review. In addition, reading the fluorescent signal in a sufficiently large number of cells for reliable individual scoring is difficult.

To avoid fading of the fluorescent signal, chromogenic in situ hybridization may be used. However, this approach is also unable to solve the problem relating to the limited number of cells that can be evaluated. Chromogenic in situ hybridization remains to be validated in prospective studies. As regards monitoring the quality of the preservation of HER-2 protein during tissue fixation and embedding, see above for ER. Combining the DNA histogram as a quality control aspect of tissue preservation with the specific quantification of HER-2 in the epithelial compartment by multiparametric analysis can be an alternative [127].

\section{EGTM Recommendation}

HER-2 should be assayed in order to select patients with advanced breast cancer for treatment with Herceptin. However, at present, HER-2 is not recommended for predicting response to adjuvant CMF, taxanes or endocrine therapy in patients with breast cancer.

HER-2 should not be used alone for determining outcome in patients with breast cancer. However, HER-2 may be combined with other prognostic factors for predicting patient outcome.

For determining the HER-2 status in breast cancer, immunohistochemistry (calibrated against FISH) should be employed. For samples with an immunohistochemistry score of $2+$, confirmation by FISH should be carried out.

Tumor Biol 2005;26:281-293 


\section{$U P A$ and $P A I-1$}

uPA is a serine protease implicated in cancer growth, invasion and metastasis [for a review, see ref. 128]. PAI-1 is an endogenous inhibitor of $\mathrm{UPA}$, but paradoxically is also involved in tumor progression [128]. Multiple single institutional studies have shown that both uPA and PAI- 1 are potent and independent prognostic factors in breast cancer $[129,130]$. This prognostic impact of UPA and PAI-1 has been shown in both lymph nodenegative and lymph node-positive breast cancer patients. Recently, the prognostic impact of uPA and PAI-1 in lymph node-negative breast cancer patients was validated in both a randomized prospective trial and a pooled analysis ( $\mathrm{n}>8,000$ patients) of single institution studies $[131,132]$.

At present, the main use of these factors lies in selecting lymph node-negative patients who do not need or are unlikely to benefit from adjuvant chemotherapy. Patients with low levels of both these proteins are at a relatively low risk of developing recurrent or metastatic disease and, consequently, may be able to avoid the toxic side effects and costs of adjuvant chemotherapy.

UPA and PAI-1 should be determined by ELISAs that have undergone both technical $[133,134]$ and clinical validation $[131,132]$. For the determination of $\mathrm{UPA}$ and PAI-1 by ELISA, a small piece of breast tumor must be rapidly frozen in liquid nitrogen following histopathological examination. Recently, a microassay (i.e. a micro ELISA) was described for the measurement of uPA and PAI-1 [135, 136]. Although not yet clinically validated, this assay showed that UPA and PAI-1 levels in core biopsies correlated well with corresponding levels in surgically removed tissue. Although multiple studies have described the use of immunohistochemistry to detect uPA and PAI-1 in breast cancer, none have shown a significant correlation with either ELISA values or patient outcome. Thus, at present, immunohistochemistry cannot be recommended for the clinical determination of UPA and PAI-1 in breast cancer.

\section{EGTM Recommendation}

According to the EGTM panel, uPA and PAI-1 may be used for determining prognosis in breast cancer, especially in the group of patients with lymph node-negative disease. ELISAs validated for both analytical and clinical performance should be used for determining these proteins.

\section{Gene Expression Profiling}

Instead of measuring individual markers, the use of DNA microarray or gene expression profiling is a popular current research approach for determining prognosis. With a microarray, the expression of tens of thousands of genes (e.g., in a sample) can be determined simultaneously. In recent years, a number of investigators have shown that microarray techniques can predict outcome in patients with breast cancer [137-141].

In one of these studies, using this technique on lymph node-negative breast cancer patients, van't Veer et al. [137] identified a 70-gene signature that correctly predicted the later appearance or absence of clinical metastasis in 65/78 lymph node-negative patients. The application of this prognostic classifier to an independent set of 19 breast cancers resulted in only two incorrect classifications.

The 70-gene expression profile was more recently validated in a series of 295 consecutive breast cancer patients [138]. In this larger study, the probability of remaining free of distant metastasis at 10 years after surgery was $85.2 \%$ in the patients with the good prognostic signature and $50.6 \%$ in those with the poor signature. The estimated hazard ratio for distant metastasis in the patients with the poor prognostic signature as compared with the group with the good prognostic signature was $5.1(95 \%$ confidence intervals $2.9-9.0 ; \mathrm{p}<0.001)$. A similar significant difference in outcome between patients with the good and poor signature was seen in patients with either lymph node-negative or lymph node-positive patients. Multivariate analysis showed that the gene signature was an independent factor in predicting disease outcome. Although these results with DNA microarray are promising, this technology is technically demanding, time-consuming and expensive. Before clinical use, this technology must be simplified, standardized and evaluated in external quality assessment schemes. Furthermore, these preliminary results must be confirmed in a large prospective study or a meta-analysis/pooled analysis of individual studies.

Rather than using large numbers of genes, Paik et al. [142] recently identified a 21-gene panel (16 test genes and 5 reference genes) that predicted breast cancer recurrence in 668 lymph node-negative ER-positive patients that received adjuvant tamoxifen therapy. Using multivariate analysis, the gene panel predicted the outcome independently of patient age and tumor size. Importantly, the authors were able to carry out RT-PCR on RNA extracted from formalin-fixed and paraffin-embedded tissue. However, as with the gene microarray results discussed above, these findings require validation in independent laboratories. 


\section{EGTM Recommendation}

Although initial results are promising, DNA microarray should not be used at present for predicting outcome in patients with breast cancer.

\section{Other Tissue-Based Markers}

Based on available evidence, a routine assay of other breast cancer tissue markers, such as p53, c-myc, cathep$\sin \mathrm{B}$, cathepsin D, S phase or ploidy [98, 134], cannot be recommended at present.

\section{Conclusions}

MUC-1 antigen and CEA are the most useful serum markers in patients with breast cancer. Serial determination of these markers may be useful in routine therapy monitoring and for early detection of recurrence and progression during follow-up. However, interpretation of sequential measurements is a task for specialists who are able to integrate information at a multidisciplinary level in collaboration with the end users, general practitioners, surgeons and oncologists. Steroid receptors and HER-2 are the tissue-based markers accepted in clinical practice, having an established role in predicting hormone sensitivity or in Herceptin treatment, respectively. UPA and PAI-1 are recently validated as prognostic factors for lymph node-negative breast cancer patients and thus may be of use in selecting those node-negative patients who may not need to receive adjuvant chemotherapy. Other potential markers for breast cancer such as $\mathrm{p} 53$, cathepsin $\mathrm{B}$, cathepsin D, S phase and ploidy look promising, but further research is necessary before their clinical utility is established.

\section{References}

$\checkmark 1$ Chu KC, Tarone RE, Kessler LG, Ries LA, Hankey BF, Miller BA, Edwards BK: Recent trends in US breast cancer incidence, survival, and mortality rates. J Natl Cancer Inst 1996; 88:1571-1579.

$\checkmark 2$ Parker SL, Tong T, Bolden S, Wingo PA: Cancer statistics 1996. CA Cancer J Clin 1996;46: $5-27$.

$\checkmark 3$ Easton DF, Bishop DT, Ford D, Crockford GP: Genetic linkage analysis in familial breast and ovarian cancer: results from 214 families. The Breast Cancer Linkage Consortium. Am J Human Genet 1993;52:678-701.

4 Colditz G, Willett WC, Hunter DJ, Stampfer MJ, Manson JE, Hennekens CH, Rosner BA: Family history, age and risk of breast cancer: prospective data from the Nurses Health Study. JAMA 1993;270:338-343.

$\checkmark 5$ Madigan MP, Ziegler RG, Benichou J, Byme C, Hoover RN: Proportion of breast cancer cases in the United States, explained by well established risk factors. J Natl Cancer Inst 1995;87:1681-1685.

6 Ekbom A, Trichopoulos D, Adami H, Hsieh CC, Lan SJ: Evidence of prenatal influences on breast cancer risk. Lancet 1992;340:10151018

7 Newcomb P, Storer B, Longnecker M, Mittendorf R, Greenberg ER, Willett WC: Pregnancy termination in relation to risk of breast cancer. JAMA 1996;275:283-287.

$\checkmark 8$ Morrow M: Identification and management of the woman at increased risk for breast cancer development. Breast Cancer Res Treat 1994; 31:53-60.
Tabar L, Fageberg CJ, Gad A, Baldetorp L, Holmberg LH, Grontoft O, Ljungquist U, Lundstrom B, Manson JC, Eklund G, et al: Reduction in mortality from breast cancer after mass screening with mammography. Randomised trial from the Breast Cancer Screening Working Group of the Swedish National Board of Health and Welfare. Lancet 1985;8433:829-832.

10 De Koning H, Boer R, Warmerdam P, Beemsterboer PM, van der Maas PJ: Quantitative interpretation of age-specific mortality reductions from the Swedish breast cancer screening trials. J Natl Cancer Inst 1995;87:1217-1223.

11 Bonadonna G, Valagussa P, Moliterni A, Zambetti M, Brambilla C: Adjuvant cyclophosphamide, methotrexate, and fluorouracil in nodepositive breast cancer: the results of 20 years of follow-up. N Engl J Med 1995;332:901-906.

12 Early Breast Cancer Trialists Collaborative Group: Systemic treatment of early breast cancer by hormonal, cytotoxic or immune therapy: 133 randomized trials involving 31,000 recurrences and 24,000 deaths among 75,000 women. Lancet 1992;339:1-15.

13 Parkin DN, Bray F, Ferlay J, Pisani P: Global cancer statistics, 2002. CA Cancer J Clin 2005; 55:75-108.

14 Early Breast Cancer Trialists Collaborative Group: Effects of radiotherapy and surgery in early breast cancer: an overview of the randomized trials. N Engl J Med 1995;333:14441455.

15 Fisher B, Anderson S, Redmond C, Wolmark N, Wickerham DL, Cronin WM: Reanalysis and results after 12 years of follow-up in a randomized clinical trial comparing total mastectomy with lumpectomy with or without irradiation in the treatment of breast cancer. $\mathrm{N}$ Engl J Med 1995;333:1456-1461.
6 Veronesi U, Luini A, Del Vecchio M, Greco M, Galimberti V, Merson M, Rilke F, Sacchini V, Saccozzi R, Savio T, et al: Radiotherapy after breast-preserving surgery in women with localized cancer of the breast. N Engl J Med 1993;328:1587-1591.

17 ASCO Expert Panel: Clinical practice guidelines for the use of tumor markers in breast and colorectal cancer. J Clin Oncol 1996;14:28432877.

18 Molina R: Tumor markers in breast cancer; in Diamandis EP, Fritsche HA, Lilja H, Chan DW, Schwartz M (eds): Tumor Markers, Physiology, Pathobiology, Technology and Clinical Applications. Washington, AACC Press, 2002, pp 165-179.

19 Bieglmayer C, Szepesi T, Kopp B, Hoffmann G, Petrik W, Guettuoche K, Grundler S, Gregorits M, Strasser M: CA 15.3, MCA, CAM 26, CAM 29 are members of a polymorphic family of mucin-like glycoproteins. Tumor Biol 1991;12:138-148.

20 Dnistrian AM, Schwartz MK, Greenberg EJ, Smith CA, Schwartz DC: Evaluation of CAM 26, CAM 29, CA 15.3 and CEA as circulating tumor markers in breast cancer patients. Tumor Biol 1991;12:82-90.

21 Gion M, Mione R, Leon AE, Lüftner D, Molina R, Possinger K, Robertson JF: CA 27.29: a valuable marker for breast cancer management. A confirmatory multicentric study on 603 cases. Eur J Cancer 2001;37:355-363.

22 Molina R, Jo J, Filella X, Zanon G, Pahisa J, Munoz M, Farrus B, Latre ML, Escriche C, Estape J, Ballesta AM: c-erbB-2 oncoprotein, CEA and CA 15.3 in patients with breast cancer: prognostic value. Breast Cancer Res Treat 1998;51:109-119. 
-23 Van Dalen A: Pre-operative tumor marker levels in patients with breast cancer and their prognosis. Tumor Biol 1990;11:189-195.

-24 Van Dalen A: Significance of cytokeratin markers TPA, TPA (cyk), TPS and CYFRA 21.1 in metastatic disease. Anticancer Res 1996;16:2345-2349.

-25 Price MR, Rye PD, Petrakou R, Murray A, Brady K, Imai S, Haga S, Kiyozuka Y, Schol D, Meulenbroek MF, Snijdewint FG, von Mensdorff-Pouilly S, Verstraeten RA, Kenemans P, Blockzjil A, Nilsson K, Nilsson O, Reddish M, Suresh MR, Koganty RR, Fortier $\mathrm{S}$, Baronic L, Berg A, Longenecker MB, Hilgers $\mathrm{J}$, et al: Summary report on the ISOBM TD-4 workshop: analysis of 56 monoclonal antibodies against the MUC1 mucin. Tumor Biol 1998; 19:1-20.

-26 Molina R, Duffy MJ, Aaronson AC, Lamerz R, Stieber P, van Dalen A, Einarsson R, Khaliffa A, Kulifay P: Tumor markers in breast cancer. EGTM recommendations. Anticancer Res 1999; 19:2803-2805.

-27 Gion M, Mione R, Nascimben O, Valsecchi M, Gatti C, Leon A, Bruscagnin G: The tumour associated antigen CA 15.3 in primary breast cancer. Evaluation of 667 cases. Br J Cancer 1991;63:809-813.

-28 Molina R, Filella X, Alicarte J, Zanon G Pahisa J, Muñoz M, Farrus B, Ballesta AM: Prospective evaluation of CEA and CA 15.3 in patients with locoregional breast cancer. Anticancer Res 2003;23:1035-1041.

$\checkmark 29$ Duffy MJ, Duggan C, Keane R, Hill ADK, McDermott E, Crown J, O'Higgins N: High preoperative CA 15-3 concentrations predict adverse outcome in node-negative and nodepositive breast cancer: a study of 600 patients with histologically confirmed breast cancer. Clin Chem 2004;50:559-563.

>30 Safi F, Kohler I, Rottinger E, Beger HG: The value of the tumor marker CA 15.3 in diagnosing and monitoring breast cancer. A comparative study with carcinoembryonic antigen. Cancer 1991;68:574-582.

-31 Soletormos G, Nielsen D, Schioler V, Skovsgaard T, Winkel P, Mouridsen HT, Dombernowsky P: A novel method for monitoring high-risk breast cancer with tumor markers: CA 15.3 compared to CEA and TPA. Ann Oncol 1993;4:861-869.

> 32 Loomer L, Brockschmidt JK, Muss HB, Saylor G: Post-operative follow-up of patients with early breast cancer. Patterns of care among clinical oncologists and a review of the literature. Cancer 1991;67:55-60.

-33 Soletormos G, Nielsen D, Schioler V, Skovsgaard T, Dombernowsky P: Tumor markers cancer antigen 15.3, carcinoembryonic antigen, and tissue polypeptide antigen for monitoring metastatic breast cancer during first-line chemotherapy and follow-up. Clin Chem 1996; 42:564-575.
34 van Dalen A, Heering KJ, Barak V, Peretz T, Cremaschi A, Geroni P, Gion M, Saracchini S, Molina R, Namer M, Stieber P, Sturgeon C, Leonard RCF, Einarsson R: Treatment response in metastatic breast cancer. A multicentre study comparing UICC criteria and tumor marker changes. Breast 1996;5:82-88.

35 Robertson JFR, Pearson D, Price MR, Selby C, Blamey RW, Howell A: Objective measurement of therapeutic response in breast cancer using tumor markers. Br J Cancer 1991;64: 757-763.

36 Tondini C, Hayes DF, Gelman R, Henderson IC, Kufe DW: Comparison of CA 15.3 and carcinoembryonic antigen in monitoring the clinical course of patients with metastatic breast cancer. Cancer Res 1988;48:4107-4112.

37 Williams MR, Turkes A, Pearson D, Twining P, Griffiths K, Blamey RW: The use of serum carcinoembryonic antigen to assess therapeutic response in locally advanced and metastatic breast cancer. A prospective study with external review. Eur J Surg Oncol 1988;14: 417-422.

38 Palazzo S, Liguori V, Molinari B: Is the carcinoembryonic antigen test a valid predictor of response to medical therapy in disseminated breast cancer? Tumori 1986;72:515-518.

39 Vizcarra E, Lluch A, Cibrian R, Jarque F, Garcia-Conde J: CA 15.3, CEA and TPA tumor markers in the early diagnosis of breast cancer relapse. Oncology 1994;51:491-496.

40 Molina R, Zanon G, Filella X, Moreno F, Jo J, Daniels M, Latre ML, Gimenez N, Pahisa J, Velasco M, et al: Use of serial carcinoembryonic antigen and CA 15.3 antigen and CA 15.3 assays in detecting relapse in breast cancer patients. Breast Cancer Res Treat 1995;36:4148.

41 Tomlinson IP, Whyman A, Barrett JA, Kremer JK: Tumor marker CA 15-3: possible uses in the routine management of breast cancer. Eur J Cancer 1995;31:899-902.

42 Molina R, Jo J, Zanon G, Filella X, Farrus B, Munoz M, Latre ML, Pahisa J, Velasco M, Fernandez P, Estape J, Ballesta AM: Utility of cerbB-2 in tissue and in serum in the early diagnosis of recurrence in breast cancer patients: comparison with carcinoembryonic antigen and CA 15.3. Br J Cancer 1996;74:11261131.

43 Jager W, Eibner K, Loffler B, Gleixner S, Kramer S: Serial CEA and CA 15.3 during follow-up of breast cancer patients. Anticancer Res 2000;20:5179-5182.

44 van Dalen A: TPS in breast cancer. A comparative study with carcinoembryonic antigen and CA 15.3. Tumor Biol 1992;13:10-17.

45 Barak V, Nisman B, Hubert A, Lyass O, Kaduri L, Peretz T: Prognostic efficacy of TPS in breast cancer. J Tumor Marker Oncol 2000;15: 4-10.

46 Dixon AR, Jackson L, Chan SY, Badley RA, Blamey RW: Continuous chemotherapy in responsive metastatic breast cancer: a role for tumor markers? Br J Cancer 1993;9:181-185.
47 Devine PL, Duroux MA, Quin RJ, McGuckin MA, Joy GJ, Ward BG, Pollard CW: CA 15.3, CASA, MSA and TPS as diagnostic serum markers in breast cancer. Breast Cancer Res Treat 1995;34:245-251.

48 Theriault RL, Hortobagyi GN, Fritsche HA, Frye D, Martinez R, Buzdar AU: The role of serum CEA as a prognostic indicator in stage II and III breast cancer patients treated with adjuvant chemotherapy. Cancer 1989;63:828-835.

49 McLaughlin R, McGrath J, Grimes H, Given HF: The prognostic value of the tumor marker CA 15.3 at initial diagnosis of patients with breast cancer. Int J Biol Markers 2000; 15:340342.

50 Ebeling FC, Schmitt UM, Untch M, Nagel D, Fateh-Moghadam A, Stieber P, Seidel D: Tumor markers CEA and CA 15.3 as prognostic factors in breast cancer - Univariate and multivariate analysis. Anticancer Res 1999;19: 2545-2550.

51 O'Hanlon DM, Kerin MJ, Kent P, Maher D, Grimes H, Given HF: An evaluation of preoperative CA 15.3 measurement in primary breast carcinoma. Br J Cancer 1995; 71:1288-1291.

52 Ebeling FG, Stieber P, Untch M, Ángel D, Konecny GE, Schmidt UM, Fateh-Moghadam A, Seidel D: Serum CEA and CA 15.3 as prognostic factors in primary breast cancer. $\mathrm{Br} \mathrm{J}$ Cancer 2002;86:217-222.

53 Molina R, Farrus B, Filella X, Zanon G, Pahisa J, Jo J, Latre MA, Muñoz M, Rivera-Fillat F: Carcinoembryonic antigen in tissue and serum from breast cancer patients: clinical applications in prognosis and in early diagnosis of relapse. Anticancer Res 1999;19:2557-2562.

54 Molina R, Filella X, Zanon G, Pahisa J, Alicarte J, Muñoz B, Farrus B, Ballesta AM: Prospective evaluation of tumor markers (c-erbB2 oncoprotein, CEA and CA 15.3) in patients with locoregional breast cancer. Anticancer Res 2003;23:1043-1050.

>55 Vyzula R, Dusek L, Zaloudik J, Demlova R, Klimes D, Selvekerova S: Breast cancer and neoadjuvant therapy: any predictive marker? Neoplasma 2004;51:471-480.

56 Chan DW, Beveridge RA, Muss H, Fritsche HA, Hortobagyi G, Theriault R, Kiang D, Kennedy BJ, Eveleigh M: Use of Truquant BR radioimmunoassay for early detection of breast cancer recurrence in patients with stage II and stage III disease. J Clin Oncol 1997; 15:23222328.

57 Nicolini A, Colombini C, Luciani L, Carpi A, Giuliani L: Evaluation of serum CA 15.3 determination with CEA and TPA in the postoperative follow-up of breast cancer patients. Br J Cancer 1991;64:154-158.

58 Nicolini A, Carpi A, Ferrari P, Anselmi L, Spinelli C, Conte M, Miccoli P: The role of tumor markers in improving the accuracy of conventional chest X-ray and liver echography in the post-operative detection of thoracic and liver metastases from breast cancer. Br J Cancer 2000;83:1412-1417. 
59 Guadagni F, Ferroni P, Carlini S, Mariotti S, Spila A, Aloe S, D'Alessandro RD, Carone MD, Cichetti A, Ricciotti A, Venturo I, Perri P, Di Filippo F, Cognetti F, Botti C, Roselli M: A re-evaluation of carcinoembryonic antigen (CEA) as a serum marker for breast cancer: a prospective longitudinal study. Clin Cancer Res 2001; 7:2357-2362.

60 Merimsky O, Inbar M, Hareuveni M, Witenberg B, Wolman Y, Chaitchik S: Serial serum MCA measurements in the follow-up of breast cancer patients. Eur J Cancer 1991;27:14401444.

-61 Pecking AP, Mechelany-Corona C, BertrandKermorgant F, Alberini JL, Floiras JL, Goupil A, Pichon MF: Detection of occult disease in breast cancer using fluorodeoxyglucose camera-based positron emission tomography. Clin Breast Cancer 2001;2:229-234.

62 Kamel EM, Wyss MT, Fehr MK, von Schulthess GK, Goerres GW: (18F)-fluorodeoxyglucose positron emission tomography in patients with suspected recurrence of breast cancer. $\mathrm{J}$ Cancer Res Clin Oncol 2003;129:147-153.

63 Nicolini A, Carpi A: Postoperative follow-up of breast cancer patients: overview and progress in the use of tumor markers. Tumor Biol 2000;21:235-248.

64 Holli K, Hakama M: Effectiveness of routine and spontaneous follow-up visits for breast cancer. Eur J Cancer Clin Oncol 1989;25:251258.

65 Schapira DV, Urban N: A minimalist policy for breast cancer surveillance. JAMA 1991; 265:380-382.

-66 Rosselli del Turco M, Palli D, Cariddi A, Ciatto S, Pacini P, Distante V: Intensive diagnostic follow-up after treatment of primary breast cancer. A randomized trial. JAMA 1994;271:1593-1597.

67 The GIVIO Investigators: Impact of follow-up testing on survival and health-related quality of life in breast cancer patients: a multicenter randomized controlled trial. JAMA 1994;271: 1587-1592.

68 The GIVIO Investigators: Impact of follow-up testing on survival and health-related quality of life in breast cancer patients: a multicenter randomized controlled trial (abstract). JAMA 1994;271:1581-1591.

-69 Legha SS, Buzdar AU, Smith TL, Hortobagy GN, Swenerton KD, Blumenschein GR, Freireich EJ: Complete remissions in metastatic breast cancer treated with combination drug therapy. Ann Intern Med 1979;91:847-852.

70 Einarsson R, Barak V: TPS: a cytokeratin serum tumor marker for effective therapy control of cancer patients with focus on breast cancer. J Clin Ligand Assay 1999;22:348-351.

-71 Lamerz R, Leonhards A, Ehrhardt H, von Lieven H: Serial carcinoembryonic antigen (CEA) determinations in the management or metastatic breast cancer. Oncodev Biol Med 1980;1:123-135.
72 Stieber P, Molina R, Chan DW, Fritsche HA, Beyrau R, Bonfrer JM, Filella X, Gomet TG, Hoff T, Jager W, van Kamp GJ, Nagel D, Peisker K, Sokoll IJ, Troalen F, Untch M, Domke I: Clinical evaluation of the Elecsys CA 15.3 test in breast cancer patients. Clin Lab 2003;49:15-24.

73 Dnistrian AM, Schwartz MK, Greenberg EJ, Smith CA, Schwartz DC: CA 15.3 and carcinoembryonic antigen in the clinical evaluation of breast cancer. Clin Chim Acta 1991;200:8193.

74 Loprinzi CL, Tormey DC, Rasmussen P, Falkson G, Davis TE, Falkson HC, Chang AY: Prospective evaluation of carcinoembryonic antigen levels and alternating chemotherapeutic regimens in metastatic breast cancer. J Clin Oncol 1986;4:46-56.

75 Van Dalen A, Barak V, Cremaschi A, Gion M, Molina R, Namer M, Stieber P, Sturgeon C, Einarsson R: The prognostic significance of increasing marker levels in metastatic breast cancer patients with clinically complete remission, or stable diseases. A multicenter study. Int $\mathbf{J}$ Biol Markers 1998;13:10-15.

76 Soletormos G, Petersen PH, Nielsen D: Computer-simulated tumor-marker data used to compare progression criteria for cytokeratin tissue polypeptide antigen in metastatic breast cancer. Clin Chem 2001;47:2035-2037.

77 van Dalen A, van der Linde DL, Heering KJ, van Oudalblas AB: How can treatment response be measured in breast cancer patients? Anticancer Res 1993;13:1901-1904.

78 Iwase H, Kobayashi S, Itoh Y, Fukuoka H, Kuzushima T, Iwata H, Yamashita T, Naitoh A, Itoh K, Masaoka A: Evaluation of serum tumor markers in patients with advanced or recurrent breast cancer. Breast Cancer Res Treat 1995; 33:83-88.

79 Soletormos G, Hyltoft Petersen P, Dombernowsky P: Progression criteria for cancer antigen 15.3 and carcinoembryonic antigen in metastatic breast cancer compared by computer simulation of marker data. Clin Chem 2000; 46:939-949.

80 Kurebayashi J, Nishimura R, Tanaka K, Kohno N, Kurosumi M, Moriya T, Ogawa Y, Taguchi T: Significance of serum tumor markers in monitoring advanced breast cancer patients treated with systemic therapy: a prospective study. Breast Cancer 2004;11:389-395.

81 Nakata B, Takashima T, Ogawa Y, Ishikawa T, Hirakawa K: Serum CYFRA 21-1 (cytokeratin-19 fragments) is a useful tumour marker for detecting disease relapse and assessing treatment efficacy in breast cancer. Br J Cancer 2004; 1:873-878.

82 Robertson JFR, Whynes DK, Dixon A, Blamey RW: Potential for cost economics in guiding therapy in patients with metastatic breast cancer. Br J Cancer 1995;72:174-177.

83 Holli K, Hakama M: Effectiveness of routine and spontaneous follow-up visits for breast cancer. Eur J Cancer Clin Oncol 1989;25:251258.
84 Schapira DV, Urban N: A minimalist policy for breast cancer surveillance. JAMA 1991; 265:380-382.

85 Sturgeon CM: Limitations of assay techniques for tumor markers; in Diamandis EP, Fritsche H, Schwartz MK, Chan DW (eds): Tumor Markers, Physiology, Pathobiology, Technology and Clinical Applications. Chicago, AACC Press, 2002, pp 65-81.

86 Sturgeon CM, Seth J: Why do immunoassays for tumour markers give differing results? - A view from the UK National External Quality Assessment Schemes. Eur J Clin Chem Clin Biochem 1996;34:755-759.

87 Zucchelli GC, Pilo A, Chiesa MR, Masini S, Clerico A: Analytical performance of CA 19.9, CA 125 and CA 15.3 assays as observed through an external quality assessment program. Int J Biol Markers 1994;9:43-47.

88 Romer M, Haeckel R, Brux B, Sinha P, Raiko I, Krieg M, et al: A multicentre evaluation of the CA 15-3 assay, CA 19-9 assay and CA 125 II assay on the Bayer Immuno 1 System. Eur J Clin Chem Clin Biochem 1997;35:637-644.

89 Hall JM, Couse JF, Korach KS: The multifaceted mechanisms of estradiol and estrogen receptor signaling. J Biol Chem 2001;276: 36869-36872.

90 Jensen EV, Jordan VC: The estrogen receptor: a model for molecular medicine. Clin Cancer Res 2003;9:1980-1989.

91 Weihua Z, Andersson S, Cheng G, Simpson ER, Warner M, Gustafsson JA: Update on estrogen signaling. FEBS Lett 2003;546:17-24.

92 Conneely OM, Lydon JP: Progesterone receptors in reproduction: functional impact of the A and B isoforms. Steroids 2000;65:571-577.

93 McGuire WL, Carbone PP, Sears ME, Escher GC: Estrogen receptors in human breast cancer: an overview; in WL McGuire, PP Carbone and EP Vollner (eds): Estrogen Receptors in Human Breast Cancer. New York, Raven Press, 1975, pp 1-8.

94 Early Breast Cancer Trialist's Collaborative Group: Tamoxifen for early breast cancer: an overview of the randomized trials. Lancet 1998;351:1451-1467.

95 Duffy MJ: Predictive markers in breast and other cancers. Clin Chem 2005;51:494-503.

96 Fleisher M, Dnistrian AM, Sturgeon CM, et al: Practice guidelines and recommendations for use of tumor markers in the clinic; in Diamandis EP, Fritsche H, Schwartz MK, Chan DW (eds): Tumor Markers, Physiology, Pathobiology, Technology and Clinical Applications. Chicago, AACC Press, 2002, pp 33-63.

97 Bast RC, Ravdin P, Hayes DF, Bates S, Fritsche H Jr, Jessup JM, Kemeny N, Locker GY, Menner RG, Somerfield MR, American Society of Clinical Oncology Tumor Markers Expert Panel: 2000 update of recommendations for the use of tumor markers in breast and colorectal cancer: clinical practice guidelines of the American Society of Clinical Oncology. J Clin Oncol 2001;19:1865-1878. 
98 European Society of Medical Oncology: Minimal clinical recommendations for diagnosis, adjuvant treatment and follow-up of primary breast cancer. http:/www.esmo.org/ reference/reference_guidelines.htm.

99 Blamey RW: EUSOMA guidelines on endocrine therapy of breast cancer. Eur J Cancer 2002;38:615-634.

100 Eifel P, Axelson JA, Costa J, Crowley J, et al: National Institute of Health Consensus Development Conference Statement: adjuvant therapy for breast cancer, November 1-3, 2000. J Natl Cancer Inst 2001;93:979-989.

101 Duffy MJ: Biochemical markers as prognostic indices in breast cancer. Clin Chem 1990; $36: 188-191$

102 Isaacs C, Stearns V, Hayes DF: New prognostic factors for breast cancer recurrence. Semin Oncol 2001;28:53-67.

103 Thorpe SM, Rose C: Oestrogen and progesterone receptor determinations in breast cancer: technology and biology. Cancer Surv 1986;5:505-525.

- 104 Harvey JM, Clark GM, Osborne CK, Allred $\mathrm{C}$ : Estrogen receptor status by immunohistochemistry is superior to the ligand-binding assay for predicting response to adjuvant endocrine therapy in breast cancer. J Clin Oncol 1999;17:1474-1481.

$>105$ Elledge RM, Green S, Pugh R, Allred DC, Clark GM, Hill J, Ravdin P, Martino S, Osborne CK: Estrogen receptor (ER) and progesterone receptor $(\mathrm{PgR})$ by ligand-binding assay compared with ER, PgR and pS2 by immunohistochemistry in predicting response to tamoxifen in metastatic breast cancer: a Southwest Oncology Group Study. Int J Cancer 2000;89:111-117.

- 106 McCarty KS Jr, Miller LS, Cox EB, Konrath $\mathrm{J}, \mathrm{McC}$ arty KS Sr: Estrogen receptor analysis. Correlation of biochemical and immunohistochemical methods using monoclonal antireceptor antibodies. Arch Pathol Lab Med 1985; 109:716-721.

107 Barnes DM, Harris WH, Smith P, Millis RR, Rubens RD: Immunocytochemical determination of oestrogen receptors: comparison of different methods of assessment of staining and correlation with clinical outcome of breast cancer patients. Br J Cancer 1996;74: 1445-1451.

108 Pertschuk LP, Feldman JG, Kim YD, Braithwaite L, Schneider F, Braverman AS, Axiotis C: Estrogen receptor immunohistochemistry in paraffin embedded tissue with ER1D5 predicts breast cancer endocrine response more accurately than $\mathrm{H} 222 \mathrm{Sp}$ gamma in frozen sections or cytosol-based ligand-binding assays. Cancer 1996;77:2514-2519.

-109 Pertschuk LP, Kim YD, Nayer K, Feldman JG, Eisenberg KB, Carter AC, Rong ZT, Thelmo WL, Fleisher J, Greene GL: Immunocytochemical estrogen and progestin receptor assays in breast cancer with monoclonal antibodies. Histopathologic, demographic and biochemical correlations and relationship to endocrine response and survival. Cancer 1990;66:1663-1670.
110 Chebil G, Bendahl PO, Ferno M, South Sweden Breast Cancer Group, North Sweden Breast Cancer Group: Estrogen and progesterone receptor assay in paraffin-embedded breast cancer, reproducibility of assessment. Acta Oncol 2003;42:43-47.

111 Leake R, Barnes D, Pinder S, Ellis I, Anderson L, Anderson T, Adamson R, Rhodes T, Miller K, Walker R: Immunohistochemical detection of steroid receptors in breast cancer: a working protocol. UK Receptor Group UK NEQAS, The Scottish Breast Cancer Pathology Group, and The Receptor and Biomarker Study Group of the EORTC. J Pathol 2000;53:634-635.

112 Fitzgibbons PL, Page DL, Weaver D, Thor $\mathrm{AD}$, Allred DC, Clark GM, Ruby SG, O'Malley F, Simpson JF, Connolly JL, Hayes DF, Edge SB, Lichter A, Schnitt SJ: Prognostic factors in breast cancer: College of American Pathologists Consensus Statement 1999. Arch Pathol Lab Med 2000;124:966-978.

113 Mohsin SK, Weiss H, Havighurst T, Clark GM, Berardo M, Roanh le D, To TV, Qian Z, Love RR, Allred DC: Progesterone receptor by immunohistochemistry and clinical outcome in breast cancer: a validation study. Mod Pathol 2004; 17:1545-1554.

114 Leers M, Nap M: Steroid receptor heterogeneity in relation to DNA index in breast cancer: a multiparameter flow cytometric approach on paraffin-embedded samples. Breast J 2001;7:249-259.

115 Leers MP, Schutte B, Theunissen PH, Ramaekers FC, Nap M: A novel flow cytometric steroid hormone receptor assay for paraffinembedded breast carcinomas: an objective quantification of the steroid hormone receptors and direct correlation to ploidy status and proliferative capacity in a single-tube assay. Hum Pathol 2000;31:584-592.

116 Olayioye MA, Neve RM, Lane HA, Hynes NE: The erbB signalling network: receptor heterodimerization in development and cancer. EMBO J 2000;19:3159-3167.

117 Slamon D, Pegram M: Rationale for trastuzumab (Herceptin) in adjuvant breast cancer trials. Sem Oncol 2001;28(suppl 3):13-19.

118 Harries M, Smith I: The development and clinical use of trastuzumab (Herceptin). Endocr Relat Cancer 2002;9:75-85.

119 Leyland-Jones B: Trastuzumab: hopes and realities. Lancet Oncol 2002;3:137-144.

120 Yamauchi H, Stearns V, Hayes DF: When is a tumor marker ready for prime time? A case study of c-erbB-2 as a predictive factor in breast cancer. J Clin Oncol 2001;19:23342356.

121 Piccart MJ, Di Leo A, Hamilton A: HER2: a predictive factor ready to use in the daily management of breast cancer patients? Eur J Cancer 2000;36:1755-1761.

122 Baselga J, Seidman AD, Rosen PP, Norton L: HER-2 overexpression and paclitaxel sensitivity in breast cancer. Therapeutic implications. Oncology 1997;11:43-48.
123 Sjostrom J, Collan J, von Boguslawski K, Franssila K, Bengtsson NO, Mjaaland I, Malmstrom P, Ostenstad B, Wist E, Valvere V, Bergh J, Skiold-Petterson D, Saksela E, Blomqvist C: c-erbB-2 expression does not predict response to sequential methotrexate and 5-fluorouracil in advanced breast cancer. Eur J Cancer 2002;38:535-542.

124 Van Poznak C, Tan L, Panageas KS, Arroyo CD, Hudis C, Norton L, Seidman AD: Assessment of molecular markers of clinical sensitivity to single-agent taxane therapy for metastatic breast cancer. J Clin Oncol 2002; 20:2319-2326.

125 Konecny G, Thomssen C, Luck HJ, Untch M, Wang HJ, Kuhn W, Eidtmann H, du Bois A, Olbricht S, Steinfeld D, Mobus V, von Minckwitz G, Dandekar S, Ramos L, Pauletti G, Pegram MD, Janicke F, Slamon DJ: Her-2/neu gene amplification and response to paclitaxel in patients with metastatic breast cancer. J Natl Cancer Inst 2004;96: 1141-1151.

126 Ross JS, Fletcher JA, Linette GP, Stec J, Clark E, Ayers M, Symmans WF, Pusztai L, Bloom KJ: The HER-2/neu gene and protein in breast cancer 2003: biomarker and target of therapy. Oncologist 2003;8:307-325.

127 Leers MP, Hoop JG, Nap M: Her2/neu analysis in formalin-fixed, paraffin-embedded breast carcinomas: comparison of immunohistochemistry and multiparameter DNA flow cytometry. Anticancer Res 2003;23: 999-1006.

128 Andreasen PA, Kjoller L, Christensen L, Duffy MJ: The urokinase-type plasminogen activator in cancer metastasis: a review. Int $\mathrm{J}$ Cancer 1997;72:1-22.

129 Duffy MJ: Urokinase plasminogen activator and its inhibitor, PAI-1, as prognostic markers in breast cancer: from pilot to level 1 evidence studies. Clin Chem 2002;48:11941197.

130 Duffy MJ, Maguire TM, Mc Dermott EW, O'Higgins N: Urokinase plasminogen activator: a prognostic marker in multiple types of cancer. J Surg Oncol 1999;71:130-135.

131 Janicke F, Prechtl A, Thomssen C, Harbeck N, Meisner C, Untch M, Sweep CG, Selbmann $\mathrm{HK}$, Graeff $\mathrm{H}$, Schmitt M, German Chemo $\mathrm{N}_{\mathrm{o}}$ Study Group: Randomized adjuvant chemotherapy trial in high-risk nodenegative breast cancer patients identified by urokinase-type plasminogen activator and plasminogen activator inhibitor type 1. J Natl Cancer Inst 2001;93:913-920.

132 Look MP, van Putten WLJ, Duffy MJ, Harbeck N, Christensen IJ, Thomsssen C, Kates R, Spyratos F, Ferno M, Eppenberger-Castori S, Sweep CG, Ulm K, Peyrat JP, Martin PM, Magdalenat H, Brunner N, Duggan C, Lisboa BW, Bendahl PO, Quilline V, Daver A, Ricolleau G: Pooled analysis of prognostic impact of biological factors UPA and PAI- 1 in 8377 breast cancer patients. J Natl Cancer Inst 2002;94:116-128. 
133 Benraad TH, Geurts-Moespot J, GrondahlHansen J, Schmitt M, Heuvel JJ, de Witte JH, Foekens JA, Leake RE, Brunner N, Sweep CG: Immunoassays (ELISA) of urokinasetype plasminogen activator (uPA): report of an EORTC/BIOMED-1 Workshop. Eur J Cancer 1996;32:1371-1381.

134 Sweep CGJ, Geurts-Moespot J, Grebenschikov N, de Witte JH, Heuvel JJ, Schmitt M, Duffy MJ, Janicke F, Kramer MD, Foekens JA, Brunner N, Brugal G, Pedersen AN, Benraad TJ: External quality assessment of trans-European multicenter antigen determination (enzyme-linked immunosorbent assay) of urokinase-type plasminogen activator (uPA) and its type 1 inhibitor (PAI-1) in human breast cancer tissue extracts. Br J Cancer 1998; 78:1434-1441.

135 Abraha RS, Thomsen C, Harbeck N, Mueller V, Baack K, Schmidt M, et al: Micromethod for determination of UPA and PAI-1 from preoperative core-needle biopsies in breast cancer (abstract 608). Breast Cancer Res Treat 2003;82:S144.
136 Schmitt M, Eickler A, Welk A, Schnelldorfer C, Harbeck N (eds): Procedure for the quantitative determination of urokinase (uPA) and its inhibitor PAI-1 in human breast cancer tissue extracts by ELISA; in Brooks S, Harris A (eds): Breast Cancer Research Protocols. Totowa, Humana Press, 2005.

137 Van't Veer LJ, Dai H, van de Vijver MJ, He YD, Hart AA, Mao M, Peterse HL, van der Kooy K, Marton MJ, Witteveen AT, Schreiber GJ, Kerkhoven RM, Roberts C, Linsley PS, Bernards R, Friend SH: Gene expression profiling predicts clinical outcome of breast cancer. Nature 2002;415:530-536.

138 van de Vijver MJ, He YD, van’t Veer LJ, Dai H, Hart AA, Voskouil DW, Schreiber GJ, Peterse JL, Roberts C, Marton MJ, Parrish M, Atsma D, Witteveen A, Glas A, Delahaye L, van der Velde $\mathrm{T}$, Bartelink $\mathrm{H}$, Rodenhuis $\mathrm{S}$, Rutgers ET, Friend SH, Bernards R: A gene expression signature as a predictor of survival in breast cancer. N Eng J Med 2002;347: 1999-2009.
139 Rogers CE, Loveday RL, Drew PJ, Greenman J: Molecular prognostic indicators in breast cancer. Eur J Surg Oncol 2002;28:467478.

140 Ramaswamy S, Ross KN, Lander ES, Golub TR: A molecular signature of metastasis in primary solid tumors. Nature Gen 2003;33: 49-54.

141 Sorlie T, Perou CM, Tibshirani R, Aas T, Geisler S, Johnsen H, Hastie T, Eisen MB, van de Rijn M, Jeffrey SS, Thorsen T, Quist H, Matese JC, Brown PO, Botstein D, Eystein Lonning P, Borresen-Dale AL: Gene expression patterns of breast carcinomas distinguish subclasses with clinical applications. Proc Natl Acad Sci USA 2001;98:1086910874.

142 Paik S, Shak S, Tang G, Kim C, Baker J, Cronin $\mathrm{M}$, Baehner R, Walker M, Watson D, Park T, Hiller H, Fisher ER, Wickerman DL, Bryant J, Wolmark N: A multi-gene assay to predict recurrence of tamoxifen-treated nodenegative breast cancer. N Engl J Med 2005; 351:2817-2826. 